удК 616.311.2.+616.314.17)-002-06:616.7

DOI 10.11603/2311-9624.2020.3.11567

(С). Т. Слобода, Л. Ю. Мінько

Львівський національний медичний університет імені Данила Галицького e-mail: lida.minko@gmail.com

\title{
Ефективність профілактики уражень тканин пародонта в осіб молодого віку з деформуючими дорсопатіями при високому рівні прогностичних ознак розвитку захворювання
}

\section{ІНФОРМАЦЯ}

Надійшла до редакції/Received: 08.08.2020 p.

Ключові слова: захворювання тканин пародонта; прогнозування розвитку; профілактика; особи молодого віку; деформуючі дорсопатії.
Вступ. Висока поширеність захворювань пародонта (ЗП) та значна інтенсивність ураження ними населення молодого віку висуває проблему їх профілактики у ряд актуальних [1-4].

\section{АНОТАЦІЯ}

Резюме. У статті висвітлено новий підхід до профілактики розвитку захворювань тканин пародонта в осіб молодого віку з деформуючими дорсопатіями шляхом визначення прогностичної значимості факторів ризику розвитку уражень тканин пародонта. На основі статистичного аналізу показників клінічного, лабораторного і функціонального досліджень визначено прогностичне значення факторів ризику розвитку захворювань пародонта в осіб молодого віку з деформуючими дорсопатіями та розроблено комплекс профілактики.

Мета дослідження - підвищити ефективність профілактики захворювань пародонта в осіб молодого віку з деформуючими дорсопатіями.

Матеріали і методи. Для оцінки вираження чинників, що сприяють розвитку та прогресуванню захворювань пародонта в осіб молодого віку з деформуючими дорсопатіями, був застосований метод альтернативного послідовного аналізу Вальда. 3 метою виявлення рівня прогностичних ознак розвитку захворювань пародонта проведено аналіз поглибленого обстеження 94 осіб молодого віку $з$ деформуючими дорсопатіями та інтактним пародонтом й визначення суми прогностичних коефіцієнтів у кожного. В осіб молодого віку з деформуючими дорсопатіями та ризиком розвитку уражень тканин пародонта було застосовано комплекс профілактики захворювань пародонта.

Результати досліджень та їх обговорення. Встановлено, що високий ризик розвитку захворювань пародонта мали 30 обстежених, що склало 31,91 \%. Не мали ризику виникнення захворювань пародонта (сума значення прогностичного коефіцієнта менша ніж 13) 64 обстежених (68,09 \%). До проведення комплексу заходів профілактики в молодих осіб із деформуючими дорсопатіями патологічних змін пародонтальних тканин не було виявлено, їх стан оцінений як здоровий, а середня сума прогностичних коефіцієнтів ризику розвитку захворювань пародонта становила $+30,6 \pm 1,23$. Через 1 рік після проведеного курсу профілактики у 29 осіб не було виявлено розвитку захворювань пародонта, що склало 96,67 \%. Через 2 роки дослідження у 27 осіб не було встановлено розвитку захворювань пародонта, що склало $90 \%$.

Висновки. Застосування запропонованого нами комплексу профілактичних заходів протягом 2-х років дозволило отримати клінічну ефективність у $90 \%$ спостережень. 
Спостереження i дослідження останніх років показали, що будь-які системні порушення в організмі людини тою чи іншою мірою відображаються у ротовій порожнині [7-9]. Особливу увагу надають захворюванням кістково-м'язової системи і зокрема деформуючим дорсопатіям (кіфоз, лордоз, сколіоз, остеохондроз), які часто діагностують у молодому віці, а деякі автори [10] відносять їх до «хвороб цивілізації».

Підходи до профілактики та лікування 3П повинні будуватися з урахуванням місцевих і загальних факторів, що відіграють провідну роль у їх патогенезі [5, 11-13], з можливим впливом на серцево-судинну [14], імунну, ендокринну, нервову та кровотворну системи [15-18]. Тому особливо важливими є пошук методів ранньої діагностики та прогнозування 3П, що дозволить проводити раціональну комплексну профілактику з урахуванням індивідуальних особливостей організму та загальносоматичної патології.

Мета дослідження - підвищити ефективність профілактики захворювань пародонта в осіб молодого віку з деформуючими дорсопатіями.

Матеріали і методи. 3 метою оцінки вираження чинників, що сприяють розвитку та прогресуванню ЗП у осіб молодого віку 3 деформуючими дорсопатіями (ДД) був застосований метод альтернативного поступового аналізу Вальда. Розрахунок величини прогностичного коефіцієнта (ПК) для кожної ознаки проводили шляхом математичної обробки отриманих значень за формулою Байєса. При досягненні математичної суми значень ПК +13 балів прогнозувався високий ризик захворювання. Суму значень ПК визначено у 94 обстежених із дД та інтактним пародонтом.

Комплекс профілактики ЗП застосовавали особам молодого віку з дД та високим ризиком розвитку уражень тканин пародонта.

Профілактика ЗП у хворих із ДД відбувалася одночасно $з$ лікуванням ДД та диспансерним спостереженням зазначеної категорії хворих лікарями-невропатологами.

Запропонований комплекс включав санацію ротової порожнини з усуненням чинників, що сприяють утворенню зубної бляшки, професійну гігієну ротової порожнини та навчання індивідуальної гігієни з вибором засобів та методів гігієнічного догляду, ірригації ротової порожнини, вібраційно-ваку- умний компресійний масаж ясен курсом 10 процедур через 2-3 доби; прийом препарату «Біотрит-Дента» по 1 таблетці 2 рази на добу протягом 2-х місяців, нормалізацію розпорядку дня, праці та відпочинку, раціональне харчування.

3 метою оцінки ефективності розробленого комплексу профілактичних заходів проводили визначення змін гігієнічних індексів, фізико-хімічних показників слини, індексу переферичного кровообігу (ІПК) та часу проходження ехосигналу на нижній щелепі.

Результати досліджень та їх обговорення. Встановлено, що високий ризик розвитку 3П (сума значення ПК досягала +13) мали 30 обстежених, що склало 31,91 \%. Не мали ризику виникнення ЗП (сума значення ПК менша ніж - 13) 64 обстежених (68,09 \%).

До проведення комплексу заходів профілактики в обстежених молодих осіб із дД патологічних змін пародонтальних тканин не було виявлено, їх стан оцінений як здоровий, а середня сума прогностичних коефіцієнтів ризику розвитку ЗП становила $+30,62 \pm 1,23$.

Через 1 рік після проведеного курсу профілактики у 29 осіб не було виявлено розвитку 3П, що склало 96,67 \%. Через 2 роки дослідження у 27 осіб не було встановлено розвитку 3П, що склало $90 \%$.

Аналіз середньостатистичних значень показників стану гігієни ротової порожнини, за індексом Green-Vermillion, фізико-хімічних показників слини, індексу переферичного кровообігу та часу проходження ехосигналу на нижній щелепі, до та після проведення комплексу профілактичних заходів наведені в таблиці.

За значенням індексу Green-Vermillion стан гігієни ротової порожнини до профілактики був задовільним $(1,47 \pm 0,06)$ бала. Через 1 рік після проведення профілактичних заходів стан гігієни ротової порожнини залишався задовільним, проте значення індексів було нижчим, ніж до профілактики $(1,13 \pm 0,07)$ бала. Через 2 роки стан гігієни ротової порожнини був добрим $(0,65 \pm 0,07)$ бала. Різниця між показниками до та після профілактики була статистично достовірною $(\mathrm{p}<0,001)$.

Швидкість салівації у обстежених осіб до проведення профілактики становила у середньому $(0,45 \pm 0,02)$ мл/хв. Через 1 рік після проведення профілактичних заходів швидкість салівації була статистично достовірно $(\mathrm{p}<0,01)$ вищою ніж до профілактики та становила 
Таблищя. Середньостатистичні значення показників стану гігієни ротової порожнини, фізико-хімічних показників слини, індексу переферичного кровообігу та часу проходження ехосигналу на нижній щелепі, до та після проведення комплексу профілактичних заходів

\begin{tabular}{|c|c|c|c|c|c|c|c|}
\hline \multirow{3}{*}{$\begin{array}{l}\text { Термін } \\
\text { спостере- } \\
\text { ження }\end{array}$} & \multirow{3}{*}{$\begin{array}{l}\text { Green - } \\
\text { Vermillion } \\
\text { (бали) }\end{array}$} & \multicolumn{3}{|c|}{ Фізико-хімічні властивості слини } & \multirow{3}{*}{\begin{tabular}{c|} 
Індекс \\
периферій- \\
ного крово- \\
обігу (бали)
\end{tabular}} & \multirow{2}{*}{\multicolumn{2}{|c|}{$\begin{array}{c}\text { Час проходження } \\
\text { ехосигналу в ділянках } \\
\text { нижньої щелепи (мкс) }\end{array}$}} \\
\hline & & \multirow{2}{*}{$\begin{array}{c}\text { швидкість } \\
\text { секреції } \\
\text { (мл/хв) }\end{array}$} & \multirow{2}{*}{$\begin{array}{l}\text { в’язкість } \\
\text { ротової } \\
\text { рідини } \\
(\mathrm{мПа/с)}\end{array}$} & \multirow{2}{*}{$\begin{array}{c}\text { pH } \\
\text { ротової } \\
\text { рідини }\end{array}$} & & & \\
\hline & & & & & & ліворуч & праворуч \\
\hline $\begin{array}{l}\text { До профі- } \\
\text { лактики }\end{array}$ & $1,47 \pm 0,06$ & $0,45 \pm 0,02$ & $1,62 \pm 0,02$ & $6,39 \pm 0,52 \#$ & $42,17 \pm 1,57$ & $15,22 \pm 0,15$ & $15,42 \pm 0,18$ \\
\hline Через 1 рік & $1,13 \pm 0,07^{* * *}$ & $0,53 \pm 0,02^{* *}$ & $1,56 \pm 0,02^{*}$ & $6,38 \pm 0,04 \#$ & $51,33 \pm 2,05^{* * *}$ & $14,68 \pm 0,11^{* *}$ & $14,82 \pm 0,12^{* *}$ \\
\hline \begin{tabular}{|l} 
Через 2 \\
роки
\end{tabular} & $0,65 \pm 0,07^{* * *}$ & $0,57 \pm 0,01^{* * *}$ & $1,49 \pm 0,01^{* * *}$ & $6,4 \pm 0,03 \#$ & $62,67 \pm 2,53^{* * *}$ & $14,15 \pm 0,09 * * *$ & $14,18 \pm 0,11^{* * *}$ \\
\hline
\end{tabular}

Примітка. Достовірність різниці показників до профілактики відносно показників через 1 та 2 роки: ${ }^{*}-$ p<0,05; ** - $\mathrm{p}<0,01 ; * * *-p<0,001 ; \#-\mathrm{p}<0,05$.

$(0,53 \pm 0,02)$ мл/хв. Аналогічну ситуацію спостерігали через 2 роки після профілактики $(0,57 \pm 0,01)$ мл/хв при $\mathrm{p}<0,001$.

Середнє значення в’язкості ротової рідини в обстежених осіб до проведення профілактики становила у середньому $(1,6 \pm 0,02) \mathrm{мПа/с.}$ Після проведення профілактики в’язкість ротової рідини статистично достовірно знизилася $((1,56 \pm 0,02) \mathrm{мПа/с} \mathrm{при} \mathrm{p}<0,05$ - через 1 рік та $(1,49 \pm 0,01) \mathrm{мПа/с} \mathrm{-} \mathrm{через} 2$ роки при $\mathrm{p}<0,001)$, ніж до профілактики.

Стан кислотності змішаної слини в обстежених осіб статистично достовірно не відрізнялася до профілактики та у віддалені терміни спостереження ( $>0,05)$.

До профілактики ІПК у середньому становив $(42,17 \pm 1,57) \%$, що свідчило про задовільний стан судин тканин пародонта. Після проведеної профілактики за запропонованою нами схемою в обстежених осіб показник ІПК статистично достовірно ( $<0,001)$ збільшувався та через рік становив $(51,33 \pm 2,05) \%$, а через 2 роки - $(62,67 \pm 2,53) \%$, що свідчило про добрий компесаторний стан судин тканин пародонта.

Швидкість проходження ехосигналу на нижній щелепі в обстежених до профілактики становила більше 15 мкс. Через рік після проведеної профілактики час проходження ехосигналу знизився до $(14,68 \pm 0,11)$ мкс ліворуч та $(14,82 \pm 0,12)$ мкс праворуч $(\mathrm{p}<0,01)$, а через 2 роки до $(14,15 \pm 0,09)$ мкс ліворуч та $(14,18 \pm 0,11)$ мкс праворуч $(\mathrm{p}<0,001)$.

Висновки. 1. Застосування запропонованого нами комплексу профілактичних заходів протягом 2-х років дозволило отримати клінічну ефективність у 90 \% спостережень. Це підтверджувалося даними змін гігієнічних індексів, фізико-хімічних показників слини, ІПК та часу проходження ехосигналу на нижній щелепі.

2. Висока ефективність запобігання розвитку ЗП у осіб молодого віку з ДД зумовлено застосуванням лікувально-реабілітаційних комплексів при деструктивних ураженнях хребта та заходів профілактики розвитку 3П (проведення раціональної гігієни ротової порожнини та ірригацій ротової порожнини, вібраційно-вакуумного компресійного масажу ясен, призначення препарату «Біотрит-Дента»), а також зміцнення соматичного здоров'я (нормалізації розпорядку дня, праці й відпочинку, раціонального харчування).

Перспективами подальших досліджень $\epsilon$ вивчення віддалених результатів ефективності профілактики захворювань пародонта в осіб молодого віку з деформуючими дорсопатіями. 
(С. Т. Слобода, Л. Ю. Минко

Львовский национальный медицинский университет имени Данила Галицкого

\title{
Эффективность профилактики поражений тканей пародонта у лиц молодого возраста с деформирующими дорсопатиями при высоком уровне прогностических признаков развития заболевания
}

\begin{abstract}
Резюме. В статье освещен новый подход к профилактике развития заболеваний тканей пародонта у лиц молодого возраста с деформирующими дорсопатиями путем определения прогностической значимости факторов риска развития поражений тканей пародонта. На основе статистического анализа показателей клинического, лабораторного и функционального исследований определено прогностическое значение факторов риска развития заболеваний пародонта у лиц молодого возраста с деформирующими дорсопатиями и разработан комплекс профилактики.

Цель исследований - повысить эффективность профилактики заболеваний пародонта у лиц молодого возраста с деформирующими дорсопатиями.

Материалы и методы. Для оценки выраженности факторов, способствующих развитию и прогрессированию заболеваний пародонта у лиц молодого возраста с деформирующими дорсопатиями был применен метод альтернативного последовательного анализа Вальда. С целью выявления уровня прогностических признаков развития заболеваний пародонта проведен анализ углубленного обследования 94 лиц молодого возраста с деформирующими дорсопатиями и интактным пародонтом и определения суммы прогностических коэффициентов у каждого. У лиц молодого возраста с деформирующими дорсопатиями и риском развития поражений тканей пародонта был применен комплекс профилактики заболеваний пародонта.

Результаты исследований и их обсуждения. Установлено, что высокий риск развития заболеваний пародонта имели 30 обследованных, что составило 31,91 \%. Не было риска возникновения заболеваний пародонта (сумма значение прогностического коэфициента меньше чем 13) у 64 обследованных (68,09 \%). К проведению комплекса мер профилактики в обследованных молодых людей с деформирующими дорсопатии патологических изменений пародонтальных тканей не было обнаружено, их состояние оценено как здоровое, а средняя сумма прогностических коэффициентов риска развития заболеваний пародонта составляла + 30,62 +1,23. Через 1 год после проведенного курса профилактики в 29 человек не было выявлено развития заболеваний пародонта, что составило 96,67 \%. Через 2 года исследования в 27 человек не было установлено развития заболеваний пародонта, что составило 90 \%. выводы. Применение предложенного нами комплекса профилактических мероприятий в течение 2-х лет позволило получить клиническую эффективность в 90 \% наблюдений.
\end{abstract}

Ключевые слова: заболевания тканей пародонта; прогнозирование развития; профилактика; молодой возраст; деформирующие дорсопатии.

(C) M. T. Sloboda, L. Y. Minko

Danylo Halytskyi Lviv National Medical University

\section{Efficiency of periodontal tissue lesions prevention in young people with deforming dorsopathies with high levels of prognostic signs of disease development}

Summary. The article highlights a new approach to the prevention of periodontal disease in young people with deforming dorsopathies, by determining the prognostic significance of risk factors for periodontal disease. Based on the statistical analysis of clinical, laboratory and functional studies, the prognostic value of risk factors for periodontal disease in young people with deforming dorsopathies is determined and a set of prevention is developed.

The aim of the study - to increase the effectiveness of prevention of periodontal disease in young people with deforming dorsopathies.

Materials and Methods. To assess the severity of factors contributing to the development and progression of periodontal disease in young people with deforming dorsopathies, was used Wald's method of alternative sequential analysis. In order to identify the level of prognostic signs of periodontal disease, an in-depth 
examination of 94 young people with deforming dorsopathies and intact periodontium was analyzed and the sum of prognostic coefficients in each was determined. A complex of prevention of periodontal diseases was used in young people with deforming dorsopathies and the risk of periodontal tissue lesions.

Results and Discussion. It was found that 30 patients had a high risk of periodontal disease developing, which were $31.91 \%$. There were no risk of periodontal disease (total value of the prognostic coefficients was less than - 13) in 64 patients (68.09\%). Before using of preventive measures complex in examined young people with deforming dorsopathies, pathological changes of periodontal tissues were not detected, their condition was assessed as healthy, and the average number of prognostic risk factors for periodontal disease was (30.62 \pm 1.23$)$. One year after prevention course, in 29 people development of periodontal disease was not detected, that were $96.67 \%$. After 2 years of study, in 27 people development of periodontal disease was not detected, that were $90 \%$.

Conclusions. The application of our proposed set of preventive measures for 2 years allowed to obtain clinical efficacy in $90 \%$ of cases.

Key words: periodontal disease; prevention; young people; deforming dorsopathies.

\section{СПИСОК ЛІТЕРАТУРИ}

1. Гасюк Н. В. Структура та поширеність хвороб пародонта у осіб молодого віку / Н. В. Гасюк // Південноукраїнський медичний журнал. - 2013. № 3. - С. 36-37.

2. Холодняк О. В. Поширеність та структура захворювань тканин пародонта в осіб молодого віку / О. В. Холодняк // Клінічна та експерементальна патологія. - 2015. - Т. 14, № 3. - С. 159-162.

3. Шварцнау Е. Г. Состояние твердих тканей зубов и пародонта у студентов медицинских учебных заведений / Е. Г. Шварцнау, И. В. Ковач // Современная стоматология. - 2015. - № 4. - С. 12-15.

4. Albandar J. M. Global epidemiology of periodontal diseases in children and young persons / J. M. Albandar, E. M. Tinoco // Periodontology 2000. - 2002. - Vol. 29, No. 1. - P. 153-176.

5. Антоненко М. Ю. Сучасні технології оптимізації комплексної профілактики захворювань пародонта / М. Ю. Антоненко, П. В. Сідельнікова // Медична наука України. - 2010. - № 1. - С. 84-89.

6. Макаренко М. В. Стан гігієни порожнини рота та визначення основних факторів ризику виникнення запальних захворювань тканин пародонта в осіб молодого віку / М. В. Макаренко // Мед. перспективи. - 2014. - T. 19, № 3. - С. 81-85.

7. Нарушения кислотно-основного равновесия в полости рта при общесоматической патологии / В. А. Румянцев, Л. К. Есаян, Е. Д. Зюзькова [и др.] // Стоматология. - 2013. - № 2. - С. 22-26.

8. Проданчук А. І. Захворювання пародонта і соматична патологія / А. І. Проданчук, I. Д. Кіюн, М. О. Кройтор // Буковинський медичний вісник. 2012. - T. 16, № 2. - C. 164-168.

9. Correspondence between dental and skeletal maturity parameters among patients with different sagittal relationships at the end of puberty period / M. Goncharuk-Khomyn, E. Akleyin, I. Zhulkevych [et al.] // J. Int. Dent. Med. Res. - 2020. - Vol. 13 (1). P. 223-228.
10. Devlin V. J. Spine secrets plus, second edition / V. J. Devlin. - USA: Elsevier, 2012. - 508 p.

11. Колесник Т. В. Эффективность комплексной профилактики и лечения воспалительных процессов у соматически здоровых лиц молодого возраста / Т. В. Колесник, О. В. Деньга // Современная стоматология. - 2013. - № 5. - С. 44-49.

12. Косенко К. Н. Стратегия профилактики основных стоматологических заболеваний с учетом их эпидемиологии и биогеохимических особенностей Украины / К. Н. Косенко, О. В. Деньга // Вісник стоматології. - 2009. - № 4. - С. 24-25.

13. Холодняк О. В. Прогностичне значення місцевих факторів ризику розвитку локалізованих запальних захворювань тканин пародонта у осіб молодого віку / О. В. Холодняк // Український стоматологічний альманах. - 2015. - № 4. - С. 33-39.

14. The interrelationship of bone and cardiovascular remodeling biomarkers and clinical peculiarities of coronary artery disease in postmenopausal women / N. S. Mykhailovska, I. O. Stetsiuk, T. O. Kulynych [et al.] // Reumatologia. - 2020. - Vol. 58 (3). - P. 142-149.

15. Герелюк В. І. Вплив стану імунної системи на перебіг генералізованого пародонтиту / В. І. Герелюк // Вісник ВДНЗУ «Українська медична стоматологічна академія». - 2013. - Т. 13, № 3 (43). - С. 22-25.

16. Шварцнау Е. Г. Динамика биохимических показателей ротовой жидкости после лечебнопрофилактических мероприятий у студентов с основными стоматологическими заболеваниями / Е. Г. Шварцнау // Современная стоматология. -2015. - № 5. - C. 22-25.

17. Preshaw P. M. Detection and diagnosis of periodontal conditions amenable to prevention / P. M. Preshaw // BMC Oral Health. - 2015. - Vol. 15, № 1. - P. 1-11.

18. Жулкевич I. В. Вікова динаміка змін стану мінеральної щільності кісткової тканини у хворих на хронічну лімфоїдну лейкемію / І. В. Жулкевич, Р. Й. Вибирана, К. В. Баранніков // Вісник наукових досліджень. - 2013. - № 1. - С. 47-50. 


\section{REFERENCES}

1. Hasiuk, N.V. (2013). Struktura ta poshyrenist khvorob parodonta u osib molodoho viku [Structure and prevalence of periodontal diseases in young people]. Pivdennoukrainskyi medychnyi zhurnal - South Ukrainian Medical Journal, (3), 36-37 [in Ukrainian].

2. Kholodniak, O.V. (2015). Poshyrenist ta struktura zakhvoriuvan tkanyn parodonta v osib molodoho viku [Prevalence and structure of periodontal disease in young aged adults]. Klinichna ta eksperementalna patolohiia - Clinical and Experimental Pathology, 14 (3), 159-162 [in Ukrainian].

3. Shvartsnau, E.H., \& Kovach, Y.V. (2015). Sostoyaniye tverdykh tkaney zubov i parodonta u studentov medytsynskykh uchebnykh zavedeniy [The state of hard tissues of teeth and periodontium in students of medical schools]. Sovremennaya stomatologiya - Modern Dentistry, (4), 12-15 [in Russian].

4. Albandar, J.M., \& Rams, T.E. (2002). Global epidemiology of periodontal diseases: an overview. Periodontology 2000, 29 (1), 7-10.

5. Antonenko, M.Yu., \& Sidelnikova, P.V. (2010). Suchasni tekhnolohii optymizatsii kompleksnoi profilaktyky zakhvoriuvan parodonta [The modern technology of optimization of complex prevention of periodontal disease]. Medychna nauka Ukrainy - Medical Science of Ukraine, (1), 84-89 [in Ukrainian].

6. Makarenko, M.V. (2014). Stan hihiieny porozhnyny rota ta vyznachennia osnovnykh faktoriv ryzyku vynyknennia zapalnykh zakhvoriuvan tkanyn parodonta $\mathrm{v}$ osib molodoho viku [Become a chihiyena empty company and the value of the main factories in ryzyk vyniknennya zapalnykh zhvoryuvan periodontal tissue in osib molodokho viku]. Med. perspektyvy Medical Prospects, 19 (3), 81-85 [in Ukrainian].

7. Rumiantsev, V.A., Esaian, L.K., \& Ziuzkova, E.D. (2013). Narusheniya kyslotno-osnovnogo ravnovesiya v polosti rta pri obshchesomaticheskoy patologii [Violations of acid-base balance in the oral cavity in case of general somatic pathology]. Stomatologiya - Dentistry, (2), 22-26 [in Russian].

8. Prodanchuk, A.I., Kiiun, I.D., \& Kroitor, M.O. (2012). Zakhvoriuvannia parodonta i somatychna patolohiia [Periodontal disease and somatic patolonia]. Bukovynskyi medychnyi visnyk - Bukovynian Medical Bulletin, 16 (2), 164-168 [in Russian].

9. Goncharuk-Khomyn, M., Akleyin, E., Zhulkevych, I., Nahirnyi, Y., Brekhlichuk, P., Mochalov, Y., ..., \& Stoika, O. (2020). Correspondence between dental and skeletal maturity parameters among patients with different sagittal relationships at the end of puberty period. J Int. Den. Med. Res., 13 (1), 223-228.

10. Devlin, V.J. (2012). Spine secrets plus, second edition. USA: Elsevier, 508.
11. Kolesnyk, T.V., \& Denha, O.V. (2013). Effektyvnost kompleksnoy profilaktiky i lecheniya vospalytelnykh protsessov u somatychesky zdorovykh lyts molodogo vozrasta [The effectiveness of complex prevention and treatment of inflammatory processes in somatic healthy individuals of young age]. Sovremennaya stomatologiya - Modern Dentistry, (5), 44-49 [in Russian].

12. Kosenko, K.N., \& Denha, O.V. (2009). Strategiya profilaktiky osnovnykh stomatologicheskykh zabolevaniy s uchetom ikh epidemiologii i biogeokhimycheskykh osobennostey Ukrainy [Strategy for the prevention of major dental diseases, taking into account their epidemiology and biogeochemical characteristics of Ukraine]. Visnyk stomatolohii - Bulletin of Dentistry, (4), 24-25 [in Russian]. 13. Kholodniak, O.V. (2015). Prohnostychne znachennia mistsevykh faktoriv ryzyku rozvytku lokalizovanykh zapalnykh zakhvoriuvan tkanyn parodonta u osib molodoho viku [Prognostic value of mass risk factors for the development of localized inflammatory protected periodontal tissues in young people]. Ukrainskyi stomatolohichnyi almanakh - Ukrainian Dental Almanac, (4), 33-39 [in Ukrainian].

14. Mykhailovska, N.S., Stetsiuk, I.O., Kulynych, T.O., Gorbachova, S.V., \& Zhulkevych, I.V. (2020). The interrelationship of bone and cardiovascular remodeling biomarkers and clinical peculiarities of coronary artery disease in postmenopausal women. Reumatologia, 58 (3), 142-149.

15. Hereliuk, V.I. (2013). Vplyv stanu imunnoi systemy na perebih heneralizovanoho parodontytu [Influence of the state of the immune system on the course of generalized periodontium]. Visnyk VDNZU "Ukrainska medychna stomatolohichna akademiia” - Bulletin of HSEI Ukraine "Ukrainian Medical Dental Academy", 13, 3 (43), 22-25 [in Ukrainian].

16. Shvartsnau, E.H. (2015). Dynamyka biokhimicheskykh pokazateley rotovoy zhydkosti posle lechebno-profilakticheskykh meropriyatiy u studentov s osnovnymy stomatologicheskymy zabolevaniyami [Dynamics of biochemic indicators of the oral fluid after treatment and prophylactic measures in students with major dental diseases]. Sovremennaya stomatologiya Modern Dentistry, (5), 22-25 [in Russian].

17. Preshaw, P.M. (2015). Detection and diagnosis of periodontal conditions amenable to prevention. BMC Oral Health, 15 (1), 1-11.

18. Zhulkevych, I.V., Vybyrana, R.Y., \& Barannikov, K.V. (2013). Vikova dynamika zmin stanu mineralnoi shchilnosti kistkovoi tkanyny u khvorykh na khronichnu limfoidnu leikemiiu [Age dynamics of changes in the state of bone mineral density in patients with chronic lymphoid leukemia]. Visnyk naukovykh doslidzhen Bulletin of Scientific Research, 1, 47-50 [in Ukrainian]. 